\title{
As Presunções e Ficções no Direito Tributário
}

\author{
Gabriela Grings Fleck
}

\section{INTRODUÇÃO}

As presunções e ficções têm recebido cada vez mais atenção por parte dos profissionais da área do Direito nos últimos anos. Trata-se de um instituto conhecido e utilizado há muito tempo no âmbito lurídico, mas tem se mostrado cada vez mais freqüente na área do Direito Tributário. Neste sentido, o presente trabalho tem como objetivo tratar de um dos assuntos recentes mais importantes e polêmicos no campo do Direito Tributário, Que são as presunções e ficções tributárias.

Este tema foi escolhido em decorrência de nos deparamos com situações capazes de suscitar inconformismo, especialmente aquelas que envolvem a atividade fiscal. O Fisco para o desempenho das suas atividades tem procurado encontrar maneiras que assegurem uma arrecadação mais eficiente e ágil e por outro lado, os contribuintes, muitas vezes, dificultam essa atividade ou tentam impedir ou burlar a ocorrência de determinados fatos geradores. Dentro desse contexto, é Que as presunções e ficções se mostram importantes no Direito Tributário.

No decorrer deste trabalho, faremos um estudo acerca dessa importância. Para tanto, faremos uma breve análise das características gerais das presunções e ficções: histórico, conceito, classificação e as diferenças entre esses dois institutos.

Após, analisaremos a possibilidade da utilização e aplicação das presunções e ficções no Direito Tributário. Falaremos sobre a possibilidade de lei tributária valer-se de presunções ou ficções ao instituir a norma de incidência. Também, é importante esclarecer quais as funções desempenhadas pelas presunções e ficções no âmbito tributário.

Ainda, abordaremos os limites ao uso das presunções e ficçōes no Direito Tributário. Nesse aspecto, trataremos das normas de competência tributária estabelecidas na Constituição Federal e da extrapolação de presunções e ficções na definição das hipóteses de incidência e na base de cálculo. 
Por fim, trataremos do fato gerador na substituição tributária para frente, mais especificamente do artigo 150 , parágrafo $7^{\circ}$, da Constituição Federal, frente à doutrinária $\mathrm{e}$ a jurisprudência. Na realidade, trata-se de um fato gerador presumido, no Qual o legislador utiliza-se de uma presunção para impor a exigibilidade de um tributo.

Assim, diante desse breve estudo, é Que procuramos demonstrar que as presunções e ficçóes são institutos presentes, importantes e, acima de tudo, necessários, no Direito Tributário brasileiro.

\section{NOÇõES DE PRESUNÇÕES E FICÇốES E A SUA UTILIZAÇÃO NO DIREITO TRIBUTARIO}

\section{1 Breve Análise sobre as Presunções e Ficções}

\subsubsection{Histórico sobre as Presunções}

No direito arcaico, os primeiros vestígios históricos do instituto das presunções encontram-se no direito hebraico, no direito indiano e no direito persa.' lá no direito romano, em Que pese haver presunções lógicas, as mesmas não eram subordinadas a nenhuma norma, exceto a presunção muciana ${ }^{2}$, tendo surgido somente com o direito justinianeu o instituto da presunção tal Qual conhecemos hoje (presunção legal). ${ }^{3}$

Na idade média, por volta dos séculos XII e XIII, é que efetivamente iniciou-se a doutrina das presunções. Entretanto, somente com o movimento das codificações, a partir do século XIX, é que o legislador estabeleceu regras sobre sua classificação e aplicação.

No ordenamento Brasileiro, as presunções surgiram com o Regimento 737, de 25 de novembro de 1850 , Que as incluiu no rol das provas. ${ }^{4}$

Após, as Constituiçóes Estaduais, tais como a do Rio de Janeiro, Pernambuco e Minas Gerais, o Código Comercial, o Código Civil de 1916, o Código Tríbutário5 , o Código de Processo Civil e o Código Civil de 2002, inclúram esse instituto em seus textos.

COVELlo, Sérgio Carłos. A Presunção em Matéria Civil. Săo Paulo: Saraiva, 1983. pg. 05.

2 Presunção muciana era aquela prevista em lei que considerava como provenientes do cônjuge varão os bens possuídos pela mulher casada, toda vez que a origem fosse desconhecida. COVELLO, Sérgio Cartos. A Presunção en Matéria Civil. São Paùo: Saraiva, 1983. pg. 8.

3 FERRAGUT, Maria Rita. Presunções no Direito Tributário. São Paulo: Dialética, 2001. pg. 53.

4 FERRAGUT, Maria Rita. Presunções no Direito Tributário. São Paulo: Dialética, 200 l. pg. 55.

5 De acordo com Maria Rita Ferragut "(...) no Código Tributário Nacional, as presunçóes estão previstas no artigo 185 (é fraudulenta a allenação ou oneração de bens ou rendas, pelo sujeito passivo em débito inscrito com a Fazenda Pública) e 204 e parágrafo único (presunçăo relativa de certeza e liquidez de divida regularmente inscrita)," FERRAGUT, Maria Rita. Presunções no Direito Tríbutário. São Paulo: Dialética, $200 \mathrm{j}$. pg. 56. 
A Constituiçãa Federal de 1988 (CF/88), em seu artigo 150, parágrafo $7^{\circ}$, acrescido pela Emenda Constitucional ( $\mathrm{EC}) n^{\circ} 03 / 93$, outorgou competência para a criação de regra presuntiva ao autorizar Que os entes políticos cobrem impostos e contribuições com base em fatos jurídicos indiciários de eventos de provável ocorrência futura ${ }^{6}$, o Que será objeto específico de análise.

De acordo com a jurista Maria Rita Ferragut:

(...) as presunções estão presentes em diversas leis ordinárias, Que contemplam pautas fiscais de valores, regime de estimativa, tributação reflexa dos sócios, sinais exteriores de rieueza, passivo fictício, preços de transferência, plantas de valores e outras $(. .)^{7}$

\subsubsection{Conceito de Presunção}

Vários são os ordenamentos estrangeiros e doutrinadores Que conceituam o vocábulo presunção. Para Sérgio Carlos Covello, tomando por base o fundamento lógico-jurídico, presunção é o convencimento antecipado da verdade provável a respeito de um fato desconhecido obtida mediante fato conhecido e conexo. ${ }^{8}$

Também, segundo Pontes de Miranda:

(...) presunção legal (praesumptio iuris) (...), em vez de meio de prova, éo conteúdo de regras jurídicas que estabelecem a existência de fato, fato jurídico, ou efeito de fato jurídico (e.g., direito), sem que se possa provar o contrário (praesumptiones iuris et de iure, presunções legais absolutas), ou enquanto não se prova o contrário (presunções legais relativas). Tais presunções se distinguem, portanto, das presunções de meio de prova, praesumptiones facti ou hominis, e das normas legais sobre provas, Que fixam a força probatória do meio de prova." (...).?

De acordo com Alfredo Augusto Becker

"(..) presunção é o resultado do processo lógico mediante o Qual, do fato conhecido cuja existência é certa, infere-se o fato desconhecido cuja existência é provável." ${ }^{10}$

6 Este é o teor do $\$ 70$, artigo 150, cuja redação fol incluída pela Emenda no 3 de 1993: "§ 7.0 A lei poderá atribuir ao suịeito passivo de obrigação tributária a condição de responsável pelo pagamento de imposto ou contribuiçăo, cujo fato gerador deva ocorrer posteriormente, assegưada a imediata e preferencial restituiçáo da Quantia paga, caso não se realize o fato gerador presumido." BRASIL. Constituição da República Federativa do Brasil, de 5 de outubro de 1988. 35 ed. Săo Paulo: Saraiva, 2005. pg. I I 5.

7 FERRAGUT, Maria Rita. Presunções no Direito Tributário. São Paulo: Dialética, 2001. pg. 56.

8 COVElLO, Sérgio Carlos. A Presunção em Matéria Civil. São Paulo: Saraiva, 1983. pg. 19.

9 MIRANDA, Pontes. Tratado de Direito Privado. 4. ed. São Paulo: Revista dos Tribunais, 1983. t. ill, pg. 420.

${ }^{10}$ BECKER, Alfredo Augusto. Teoria Geral no Direito Tributário. 3. ed. São Paulo: Lejus, 1998. pg. 508. 
Segundo Paulo Celso Bergstrom Bonilha:

(...) presunção é, assim, o resultado do raciocínio do julgador, Que se guia nos conhecimentos gerais universalmente aceitos e por aquilo que ordinariamente acontece para chegar ao conhecimento do fato probando. É inegável, portanto, Que a estrutura desse raciocínio é a do silogismo, no Qual o fato conhecido situa-se na premissa menor e o conhecimento mais geral da experiência constitui a premissa maior. A conseqüência positiva resulta do raciocínio do julgador e é a presunção. "

Para Igor Tenório e 1. Motta Maia presunção é:

Meio de prova consistente em conclusões ou deduções Que se podem extrair de um fato conhecido para chegar-se a aceitar como verdadeira e provada a existência de outro fato. É meio de prova indireta. Presunção absoluta, presunção comum são duas modalidades distintas pelas suas conseQüências. No primeiro caso, se trata da chamada presunção jurídica, a que não se admite prova em contrário. No segundo caso, elas caracterizam os indícios, ou presunções do homem. ${ }^{12}$

Por fim, no dizer de Maria Rita Ferragut:

O vocábulo presunção detém mais de uma definição, posto tratar-se de proposição prescritiva, relação e fato. (...) Como proposição prescritiva, presunção é norma jurídica deonticamente incompleta (norma latu sensu). de natureza probatória Que, a partir da comprovação do fato diretamente provado (fato indiciário, fato diretamente conhecido, fato implicante) implica juridicamente o fato indiretamente provado (fato indicado, fato indiretamente conhecido, fato implicado).

Constitui-se, com isso, uma relação, vínculo jurídico Que se estabelece entre o fato indiciário e o aplicador da norma, conferindo-lhe o dever e o direito de construir indiretamente un fato.

lá como fato, presunção é conseQüente da proposição (conteúdo do conseQüente do enunciado prescritivo), Que relata um evento de ocorrência fenomênica provável e passível de ser refutado mediante apresentação de provas contrárias. É prova indireta, detentora de referência objetiva, localizada em tempo histórico e espaço social definidos. ${ }^{13}$

"BONILHA, Paulo Celso Bergstrom. Da Prova no Processo Administrativo Tributário. 2. ed. São Paulo: Dialética, 1997. pg. 92/93.

${ }^{12}$ TENÓRIO, lgor e MAIA, J. Mota. Dicionário de Direito Tributário. São Paulo: José Bushatskey, 1975. pg. 315.

13 FERRAGUT, Maria Rita, Presunções no Direito Tributário. São Paulo: Dialética, 2001. pg. 62. 


\subsubsection{Classificação das Presunçōes}

As presunções, de acordo com a classificação tradicional, poden ser classificadas utilizando-se dois critérios fundamentais: o da procedência e o da força probante. ${ }^{14}$

Quanto ao critério da procedência, as presunçōes podem ser classificadas em legais ${ }^{15}$ (iuris), Quando elaboradas pelo legislador e impostas como normas jurídicas em razão do interesse público, e comuns ou judiciais, humanas (hominis), se construídas pelo aplicador da norma.

lá no Que tange à força probante, as presunções podem ser relativas (iuiris tantum), admitindo prova em contrário ${ }^{16}$, e absolutas (iuris et de iure). Que são aquelas que se impõem como verdade absoluta, não admitindo prova em contrário.

Entretanto, a classificação tradicional recebe inúmeras críticas de diversos doutrinadores.

Assim, a melhor classificação é aquela que leva em consideração três critérios fundamentais, Quais sejam, o da procedência, o da finalidade jurídica e o da matéria. ${ }^{17}$

O critério da procedência classifica as presunções em dois grandes grupos: as comuns, advindas de uma elaboração mental do magistrado, e as legais, fruto do Poder Legislativo.

lá pelo critério da finalidade jurídica, as presunções são classificadas em três categorias: as Que visam a permitir a produção de certos efeitos jurídicos, as Que visam reconhecer a modalidade de uma relação jurídica já constituída e as Que reconhecem o desfazimento de uma relação jurídica.

Por fim, no Que tange ao critério da matéria, as presunções classificam-se em: relativas às pessoas, aos bens e à propriedade, às sucessões, às obrigações eà família. Ainda, sob esse aspecto é Que podemos classificar as presunções em civis, penais, comerciais, trabalhistas e tributárias. ${ }^{18}$

14 Iso Chaitz Scherkerwitz classifica as presunçóes pelo critério da procedência como sendo Quanto a sua origem, Que se subdivide em presunçōes simples ou comuns, Que são aQuelas que são consequiência do próprio raciocínio do homem em face dos acontecimentos que observa ordinariamente, e presunçóes legais ou de direito, Que são estabelecidas pela lei. lá quanto ao critério da força probante, o mesmo autor classifica as presunções de acordo com a possibilidade de produçâo de prova contrária. Assim, as presunções legais poderiam ser subdivididas em presunções relativas, Que comportan dilação probatória em sentido contrário, presunçöes mistas, Que apenas admitem contra a verdade por elas estabelecidas os meios de prova referidos e previstos na própria norma e presunções absolutas, Que não comportam dilação probatória em sentido contrário. SCHERKERKEWITZ, Iso Chaitz. Presunções e Ficções no Direito Tributário e no Direito Penal Tributário. Rio de Janeiro: Renovar, 2002. pg. 32/33.

15 Maria Rìta Ferragut diz que: "Presunções legais são normas jurídicas latu sensu que nada presumem juridicamente, mas estabelecem como verdadeiro fato descritor de cvento cuịa ocorrência é indiretamente provada. (...) essas normas visam suprir deficiências probatórias, ao disciplinar o procedimento de construção de fatos jurídicos." FERRAGUT, Maria Rita. Presunções no Direito Tributárịo. São Paulo: Dialética, 2001. pg. 13.

16 Nesse sentido: BRASIL. Supremo Tribunal Federal. Recurso Extraordinário $\eta^{\circ}$ 67 14.6/MG, da I Turma do STF, Relator Ministro Luis Gałotti, Brasília, Df 28/1 1/1969.

${ }_{17}$ COVELlo, Sérgio Carlos. A Presunção em Matéria Civill. São Paulo: Saraiva, 1983.pg. 30/31.

18 COVELLO, Sérgio Carlos. A Presunção em Matéria Civil. São Paulo: Saraiva, 1983. pg. 32/34. 
Consoante Maria Rita Ferragut, a generalidade e abstração, a existência vinculada à ocorrência de fatos indiciários e o conteúdo do fato indiciado são os critérios Que classificam as presunções legais. ${ }^{19}$

\subsubsection{Conceito de Fíç̧ẫo}

A ficção é uma criação do legislador que faz uma valoração jurídica, dentro de uma norma legal, de um fato pré-jurídico Que acontece no mundo natural, desvínculando desse fato os seus efeitos normais, criando, assim, uma verdade jurídica diferenciada da verdade real. ${ }^{20}$

Maria Rita Ferragut diz que as ficções jurídicas (fictio juris) são regras de direito material Que criam uma verdade legal contrária à verdade natural, ou seja, alteram a representação da realidade ao criar uma verdade jurídica Que não the corresponde ou, ainda, "produzem efeitos jurídicos prescindindo da existência empírica dos fatos típicos Que originariamente ensejariam tais efeitos. ${ }^{21}$

O doutrinador Luciano Amaro é incisivo ao dizer Que a ficção no plano jurídico é de utilização privativa do legislador, atribuindo a lei a determinado fato características que, sabidamente, não são reais. ${ }^{22}$

\subsubsection{Classificação das Ficções}

As ficções podem ser classificadas em históricas e dogmáticas. ${ }^{23}$

As ficçôes históricas são ąuelas verdades jurídicas criadas pelo legislador, visando disciplinar acontecimentos novos, adaptando-se às instituições já existentes e as ficções dogmáticas são aquelas Que resultam de uma apuração puramente intelectual. ${ }^{24}$

\subsubsection{Diferenças entre Presunções e Ficções}

Sobre essa Questão Leonardo Sperb de Paola ensina Que:

(...) o Que diferencia o instituto das presunções das ficções é o relacionamento entre o fato conhecido do fato desconhecido. Eneuanto naquelas essa relação é provável, nestas pelo contrário, é improvável ou, desde logo, sabida

19 A doutrinadora Maria Riła Ferragut, em sua obra, explica cada um dos critérios utilizados para classificar as presunções legaiss. FERRAGUT, Maria Rita. Presunções no Direito Tributário, Săo Paulo: Dialética, 2001. Pg. 66.

20 SCHERKERKEWITZ, Iso Chaitz. Presunções e Ficções no Direito Tributário e no Direito Penal Tributário. Rio de Janeiro: Renovar, 2002. pg. 35/36.

2) FERRAGUT, Maria Rita, Presunçōes no Direito Tributário. São Paulo: Dialética, 2001. pg. 85.

22 AMARO, Luciano. Direito Tributário Brasileiro. 6. ed. Säo Paưlo: Saraiva, 2001. pg. 258.

${ }^{23}$ SCHERKERKEWITZ, Iso Chaitz. Presunções e Ficções no Direito Tributário e no Direito Penal Tributário. Rio de laneiro: Renovar, 2002. pg. 38/39

${ }^{24} \mathrm{Liz}$ Coll Cabral Nogueira ap̧ud SCHERKERKEWITZ, Iso Chaitz. Presunçōes e Ficções no Direito Tributário e no Direito Penal Tributário. Rio de laneiro: Renovar, 2002. pg. 38. 
inexistente. Para alguns, a idéia de probabilidade, maior ou menor, deve ser, de plano, excluída, no caso das ficções. Assim, as ficções sempre implicariam falseamento da realidade, por via de equiparações entre coisas Que nela não se equiparam. ${ }^{25}$

O tributarista Luciano Amaro estabelece uma fundamental diferença entre o instituto das presunções e o da ficção jurídica, ao dizer Que:

A ficção jurídica não se confunde com a presunção absoluta, embora, praticamente, dela se aproxime. Na presunção absoluta, a conseqüência do fato conhecido é provável, embora passível de dúvida, mas a lei valoriza a probabilidade e recusa a prova em contrário. Na ficção, não há dúvida sobre o fato real, mas a lei, conscientemente, nega a realidade fática e constrói uma realidade jurídica diversa daquela. Dada a própria natureza da ficção, não cabe sequer cogitar-se de prova em contrário. ${ }^{26}$

Também, Jackson Borges de Araújo, fazendo uma análise da distinção entre as presunçôes legais absolutas e as ficções jurídicas, com base no entendimento de Pérez de Alaya, diz que as ficções jurídicas se colocam fora do campo da prova e toma como verdade jurídica o Que é falso e improvável. ${ }^{27}$

A presunção absoluta cria uma relação entre duas realidades ou fatos naturais, com o intuito de facilitar a prova do fato presumido; por outro lado, a ficção jurídica cria uma realidade jurídica que não há na realidade natural ou que não corresponde à realidade físico-natural em nenhum sentido, não guardando, assim, QualQuer relação de causalidade com ela. ${ }^{28}$

\subsection{As Presunģões e Fiç̧ões no Direito Tributário} Tributário

1.2.1 Possibilidade do Uso das Presunções e Ficções no Direito

Há doutrinadores que Questionam a possibilidade de lei tributária valer-se de presunções ou ficções ao instituir a norma de incidência. Segundo eles, se o emprego dessas técnicas implicar afronta, mesmo que de modo indireto, a Qualeuer princípio constitucional, esses institutos devem ser repelidos. ${ }^{29}$

25 PAOLA, Leonardo Sperb de. Presunçōes e Ficções no Direito Tributário. Belo Horizonte: Del Rey, 1997. pg. 76.

${ }_{26}$ AMARO, Luciano. Direito Tríbutárío Brasileiro. 6. ed. São Paulo: Saraiva, 2001. pg. 258.

${ }^{27}$ Pérez de Alaya apud ARAúlo, jakson Borges. ICMS Ficção do Fato Gerador na Substituição Tributária. Säo Paulo: Juarez de Oliveira, 2001.pg. 89

28 Pérez de Alaya apud ARAúlOO, Jakson Borges. ICMS Ficçäo do Fato Gerador na Substituiçăo Tributária. São Paulo: Juarez de Oliveira, 2001.pg. 89/90. Na sua obra, o doutrinador utiliza um exemplo citado por Pérez de Alaya para explicar a diferença existente entre as presunçôes absolutas e as ficçőes jurídicas.

29 AMARO, Luciano. Direito Tributário Brasileiło, 6. ed. São Paulo: Saraiva, 2001, pg. 258. 
Assim defende lves Gandra da Silva Martins, Que sustenta Que as presunções e as ficções não podem ser adotadas no Direito Tributário brasileiro, em face dos princípios da estrita legalidade, da tipicidade fechada, da vedação da integração analógica impositiva e da benigna ampliada. E nesse sentido aduz:

A presunção é inadmissível do ponto de vista de doutrina pura, porQue nem a lei pode criar presunção absoluta em eventual conflito com os fatos, nem pode permitir presunção relativa em detrimento do sujeito passivo, sem ferir a "tipicidade cerrada", Que deve acompanhar permanentemente, o "perfil da imposição". A "ficção legal" não pode ser adotada, porQue a lei não tem o direito de criar "mentira oficial" em desacordo com o retrato constitucional e complementar da imposição. ${ }^{30}$

Também, há Quem afirme que o princípto da capacidade contributiva por si só impede o uso de presunções absolutas e ficções no âmbito do Direito Tributário. ${ }^{3 !}$

Porém, Luciano Amaro, citando o entendimento de Gilberto Ulhôa Coelho, refere ser legal o recurso do legislador às ficções e presunçōes sempre que a verdade legal por esse meio declarada não esteja, expressamente ou implicitamente, em desacordo com a verdade legal enunciada pela norma superior. ${ }^{32}$

Leonardo Sperb de Paola diz Que:

As presunçōes e ficções, em Direito Tributário, não são fenômenos periféricos. Pelo contrário, são encontráveis em praticamente todos os tributos. São utilizados tanto nas normas Que criam a obrigação tributária, como nas Que dispõe sobre o processo administrativo tributário. ${ }^{33}$

No Que tange especificamente ao uso das ficções no Direito Tributário, há posição contrária na doutrina brasileira. Para essa corrente, não é possivel a utilização desse instiłuto no âmbito tributário, tendo em vista ser inconstitucional a sua utilização para a criação de obrigações tributárias, já Que na ficção jurídica considera-se como verdadeiro aquilo Que, da perspectiva fenomênica, é falso, ou seja, tem como fato jurídico tributário um fato Que, diante da realidade fática e jurídica comprovada, não é. ${ }^{34}$

Segundo esse entendimento, a utilização de fiç̧ões viola diversos princípios constitucionais, tais como legalidade, tipicidade e a discriminação de competências, além de implicar em um alargamento da regra-matriz da incidência tributária, sem fundamento de validade na Constituição Federa!. ${ }^{35}$

30 Ives Gandra da Silva Martins apud ARAúlOO, Jakson Borges. ICMS Ficção do Fato Gerador na Substituição Tributária. São Paulo: luarez de Oliveira, 2001.pg. 96.

31 ARAújO, Jakson Borges. ICMS Ficção do Fato Gerador na Substituição Tributária. Săo Paulo: |uarez de Oliveira, 2001. pg. 98.

32 AMARO, Luciano. Direito Tributário Brasileiro. 6. ed. São Paulo: Saraiva, 2001. pg. 258

33 PAOLA, Leonardo Sperb de. Presunçōes e Ficçōes no Direito Tributário. Belo Horizonte: Del Rey, 1997. pg. 97.

${ }^{34}$ FERRAGUT, Maria Rita. Presunçōes no Direito Tributário. São Paulo: Dialética, 2001 . pg. 88.

${ }^{35}$ FERRAGUT, Maria Rita. Presunçōes no Direito Tribułário. São Paulo: Dialética, 2001 . pg. 88 
lá Susy Gomes Hoffmann, ao tratar do tema das presunções e indícios como meios de provas no processo administrativo tributário, diz que somente poderão ser aceitas, no direito, as presunções legais e afirma Que:

(...) como meio de prova no Direito Tributário, tenos que somente valerão, segundo nosso entendimento, nos casos expressos em lei e desde que respeitados os princípios da legalidade e da tipicidade legal, isto é, o fato jurídico tributário deve se enquadrar em todos os critérios definidos na classe de fatos constante do suposto da norma geral e abstrata que impõe a incidência tributária. ${ }^{36}$

Nesse mesmo sentido, discorreu Luiz Eduardo Schoueri:

(...) a razão porque não cabe o emprego de presunçōes simples em lugar das provas é imediata: estando o sistema tributário brasileiro submetido à rigidez do princípio da legalidade, a subsunção dos fatos à hipótese de incidência tributária é mandatória para Que se dê o nascimento da obrigação do contribuinte. Admitir que o mero raciocínio de probabilidade por parte do aplicador da lei substituta a prova é conceber a possibilidade - ainda que remota diante da altíssima probabilidade que motivou a ação fiscal - de que se possa exigir um tributo sem que necessariamente tenha ocorrido o fato gerador. ${ }^{37}$

Porém, Quanto à existência de presunções legais no âmbito tributário, podemos citar a seguinte ementa como exemplo:

ICM. Diferença de controle. Presunção legal, estabelecida no artigo 211 . inciso Il, do RICMSC (Lei 4283/69, art. 23) é de natureza "juris tantum". Alegações insubsistentes não a elidem. Notificação mantida. Decisão confirmada. ${ }^{38}$

Quanto ao uso das presunçóes simples no Direito Tributário, a sua aplicação deve reunir três requisitos: seriedade quanto à necessidade de um nexo evidente entre o fato conhecido e sua conseqüência; precisão Quanto à idoneidade do fato conhecido e a concordância a respeito da relação entre os fatos para se chegar à conclusão Que se pretende demonstrar, cercada de absoluta certeza. ${ }^{39}$

36 HOffMANN, Susy Gomes. Teoria da Prova no Direito Tributário. São Paulo: Copola Livros, 1999. pg. $216 / 217$

${ }^{37}$ Luiz Eduardo Schoueri apud HOFFMANN, Susy Gomes. Teoria da Prova no Direito Tributário. São Paulo: Copola Livros, 1999. pg. 217.

${ }^{38}$ BRASIL. Conselho de Contribuintes. Processo $\pi^{\circ}$ CO $3-0097 / 86-1$, Conselho de Contribuintes de Santa Catarina, Relator Cons. Alcides Vettorazi, Santa Catarina, D) 02.03.1988. Em: SOARES, Carlos Dalmiro da Silva. Efeitos e Natureza Jurídica do Parcelamento Administrativo de Créditos Tributários. Disponível em: $<$ http://wwwl.jus.com.br/doutrina/texto.asp?td=1338>. Acesso em: 17 nov. 2004.

39 BONILHA, Paulo Celso Bergstrom. Da Prova no Processo Administrativo Tributário. 2. ed. São Paulo: Dialética, 1997. pg. 96. 
Na prática, Quanto à utilização das presunções simples para servir de fundamento na autuação emitida pelo Fisco, o Conselho do Contribuinte, no acórdão n 107-06.229, de 22.03.2001, estabeleceu Que:

Nas presunções simples é necessário que o fisco esgote o campo probatório. A atividade do lançamento tributário é plenamente vinculada e não comporta incertezas. Havendo dúvida sobre a exatidão dos elementos em que se baseou o lançamento, a exigência não pode prosperar, por força do disposto no art. 122 do CTN. ${ }^{40}$

Do conteúdo do voto, cuj̣o Relator foi o Conselheiro Luiz Martins Valero, extraemse as seguintes ponderações:

(...) o Fisco não pode autuar unicamente com base em indício, por não ter este a força probatória de uma genuína presunção. Vale dizer, diferentemente das presunções legais, a autuação lastreada, apenas no primeiro, e muitas vezes único, elemento colhido pelo Fisco não encontra guarida no bom Direito. A presunção simples, na Qualidade de prova indireta, somente é meio idôneo para referendar uma autuação Quando resultar da soma de indícios convergentes. Se todos os fatos levarem ao mesmo ponto, a prova da omissão de receitas restará assegurada. ${ }^{4 t}$

\subsubsection{Funções desempenhadas pelas Presunções e Fịcções no Direito Tributário}

Primeiramente, cumpre salientar Que são duas as principais funções gerais das presunções. Por primeiro, no plano judiciário, a sua existência vem da dificuldade de provar determinados fatos por via direta, apresentando-se como um meio de prova. Por segundo, no plano legislativo, a presunção corresponde à necessidade de dar estabilidade e economia às relaçôes jurídicas.

De um modo geral, podemos dizer Que essa técnica jurídica, Qual seja, a instituição de presunções legais serve para dar certeza às relações e facilitar as provas, construindo certas verdades considerando inequívocas determinadas situações a partir da constatação de certos fatos ou realização de determinados atos. ${ }^{42}$

40 PROLIK, Escritório Augusto. As Presunçôes Fiscais e o Lançamento Tributário. Disponível em: <htț:// uww.prolik.com.br/34-0 I.html>. Acesso em 17 nov. 2004.

4l PROLIK, Escritório Augusto. As Presunçōes Fiscais e o Lançamento Tributário. Disponível em: <http:// wuw.prolik.com.br/34-01.html >. Acesso em 17 nov. 2004.

42 SOARES, Carlos Dalmiro da Silva. Efeitos e Natureza |urídica do Parcelamento Administrativo de Créditos Tributários. Disponivel em: <http://wwwl.jus.com.br/doutrina/texto.asp?id=1338>. Acesso em; 17/ $11 / 2004$. 
Os nossos tribunais têm admitido a utilização do recurso das presunções como meio de evitar a sonegação fiscal. ${ }^{43}$

De acordo com Sérgio Carlos Covello, "na impossibilidade de alcançar diretamente o fato, o legislador vale-se do expediente da técnica jurídica Que se denomina presunção, para atingi-lo e elaborar a regra adequada. ${ }^{44}$

As presunções absolutas e as ficções jurídicas exercem, segundo lackson Borges de Araújo, na esfera do Direito Tributário, as mesmas funções que desempenham nos outros ramos do direito, resumindo-as na denominada função "redução simplificadora dos elementos substanciais do Direito", cuja expressão é do doutrinador François Geny. ${ }^{45}$

Leonardo Sperb de Paola ensina Que são três as principais funções cumpridas pelas presunçōes e ficções no Direito Tributário, euais sejam: auxiliar na busca da riqueza do contribuinte, aumento da eficácia de arrecadação (potencialização da eficácia arrecadatória) e combate à sonegação de tributos. ${ }^{46}$

O jurista Paulo Celso Bergstrom Bonitha, em sua obra Da Prova no Processo Administrativo Tributário, cita o comentário de Lucien Mehl, com relação à função das presunções legais com o intuito de deslocar o ônus da prova para o contribuinte, referindo:

Além do mais e não obstante as regras gerais, a vontade de lutar contra a fraude fiscal conduz o legislador a editar presunções legais, Que não podem ser evitadas a não ser que o contribuinte produza a prova em contrário (doações a título gratuito, distribuição de lucros) e a deixar a carga da prova para o contribuinte lançando de oficio, em conseoüência de sua negligência ou de irregularidades graves. ${ }^{47}$

Ao abordar o tema da causa da existência das presunçōes; Maria Rita Ferragut, diz Que apenas as razões de aumento da arrecadação não justificam por si só a utilização das presunções no Direito Tributário, tendo em vista Que o ordenamento jurídico dá ao Poder Legislativo outras formas para a instituição de tributos. ${ }^{48}$

Ainda, para ela, um dos motivos para a criação das presunções no Direito Tributário foi o de "sanar a dificuldade de se provar certos fatos mediante prova direta", pois muitos fatos relevantes são muitas vezes ocultados por meio de fraudes à lei fiscal, além de colaborar

${ }^{43}$ SOARES, Carlos Dalmiro da Silva. Efeitos e Natureza Jurídica do Parcelamento Administrativo de Créditos Tribulários. Disponivel en: <http://wwwi.jus.com,br/doutrina/texto.asp?id=1338>. Acesso em; [7/1 1/2004.

14 COVElLo, Sérgio Carlos. A Presunção em Matéria Civil. Săo Paulo: Saraiva, 1983. pg. 2.

45 ARAúlO, lackson Borges. ICMS Fiç̧ão do Fato Gerador na Substituiçäo Tributária. Săo Paulo: luarez de Oliveira, 2001. pg. 91.

4 PAOLA, Leonardo Sperb de. Presunções e Ficções no Direito Tributário. Belo Horizonte: Del Rey, 1997. pg. 98/113.

47 Lucien Mehl apud BONiLHA, Paulo Celso Bergstrom. Da Prova no Processo Administrativo Tributário. 2. ed. Săo Paulo: Díalética, 1997 pg. 95.

48 FERRAGUT, Maria Rita. Presunções no Direito Tributário. São Paulo: Dialética, 2001. pg. 80/81. 
para a atividade arrecadatória, através da simplifícação da arrecadação, Quando a prova direta é impossivel ou dificil de ser produzida. Assim, mesmo nesse segundo caso (arrecadação) as presunçōes visam suprir deficiências probatórias. ${ }^{49}$

Por fim, refere Que minoritariamente as presunçōes foram criadas para "preservar o interesse público, a estabilidade do sistema e a segurança das relaçōes sociais, tais as presunções de constitucionalidade das leis e certeza e liquidez da dívida inscrita, estas contidas no artigo 204 do Código Tributário Nacional (CTN) ${ }^{50 "} .51$

\section{LIMITES AO USO DAS PRESUNÇÕES E FICÇÓES NO DIREITO TRIBUTÁRIO}

Conforme já analisando no item anterior, em que pese haver entendimento doutrinário contrário ao uso das presunções no Direito Tributário, a sua utilização é cada vez mais freqüente. As presunçôes têm se apresentado como um meio seguro e eficaz no desempenho da função do Fisco, tendo em vista a falta de colaboração dos contribuintes em muitos casos.

Contudo, esse instituto não pode ser utilizado de forma arbitrária pelo Fisco, sob pena de descaracterizar a função essencial desse instituto no Direito Tributário (praticabilidade e arrecadação). Dessa forma, as limitaçôes na utilização das presunções e ficções visam combater eventual arbitrariedade e abuso, pois instituem limites que devem ser observados Quando da definição das hipóteses de incidência, dando segurança aos contribuintes.

Nesse aspecto, o estudo da discriminação de competências mostra-se extremamente relevante no que tange aos limites da utilização das presunçóes e ficções no âmbito tributário, tendo em vista Que a própria Constituição é Quem estabelece as limitações ao poder de tributar e as regras de competência, não podendo o legislador infraconstitucional (também ao prever presunçốes e ficçốes) extrapolar tais limites e os conceitos indeterminados contidos na Constituição.

17 FERRAGUT, Maria Rita. Presunções no Direito Tributário. São Paulo: Dialética, 2001. pg. 80/81.

so Assim: "Art. 204. A divida regularmente inscrita goza da presunção de certeza e fieuidez e tem o efeito de prova pré-constituída. "Parágrafó único. A presunção a que se refere este artigo é rełativa e pode ser ilidida por prova inequivoca, a cargo do sujeilo passivo ou do terceiro a que aproveite." BRASIL. Código Tributário Nacional. 29. ed. São Paulo: Saraiva, 2000. pg. 88/89.

5! FERRAGUT, Maria Rita. Presunções no Direito Tributário. São Paulo: Dialética, 2001. pg. 81. 


\subsection{As Implicações das Presunçóes e Ficções frente às Normas de Competência Tributária}

2.1.I Extrapolação de Presunções e Ficções na Definição de Hipótese de Incidência

No Direito Tributário brasileiro, os limites ao uso das presunções e ficções se dão através dos Princípios Constitucionais e da discriminaçâo de competências estabelecida na Constituição Federal de $1988^{52} \cdot{ }^{53}$

Quanto aos princípios constitucionais, lakson Borges de Araújo relata Que:

(...) tanto o princípio da igualdade (art. 150, II, CR/88), como o da capacidade econômica do contribuinte (art. 145, $1^{\circ}, \mathrm{CR} / 88$ ), constituem os dois maiores e mais importantes limites à ação do legislador e do aplicador da norma tributária, na criação de normas remissivas de presunções e ficções jurídicas. ${ }^{54}$

Todos esses limites, Que devem ser observados pelo legislador na definição das hipóteses de incidências e nas bases de cálculo, têm como objetivo dar maior segurança ao contribuinte e impedir a invasão de competência de um ente sobre o outro, haja vista Que a válvula de escape do sistema está na atribuição da competência residual à União. ${ }^{55}$

Tanto a divisão constitucional de competências, como as garantias constitucionais de Que os contribuintes são titulares informam o exercício da função de tributar. ${ }^{56}$

Para Iso Chaitz Scherkerkewitz:

Todo o fenômeno tributário brasileiro é expressamente delineado pela Constituição Federal. A nossa carta é minuciosa ao definir o nosso sistema tributário. Inúmeros princípios estão expressamente firmados no texto constitucional, e estes princípios servem, entre outros objetivos, para evitar as deformaçōes do fenômeno tributário. ${ }^{57}$

52 Humerto Ávila, tratando a respeito das características do Sistema Tributário Nacional, nos ensina que: "A Constituição Brasiteira tem, (...), um título específico (...) Que regula tanto o "Sistema Tributário Nacional" (..) Quanto as "Finanças Públicas" (...) A determinação de um ordenamento constitucional formulado especificamente para um âmbito matcrial faz com Que o Direito Tributário (e Financeiro) Brasileiro tenha seu fundamento (embora não excluindo) na própria Constituiçāo: os princípios gerais, as limitaçōes ao poder de tributar e as regras de competência da União, dos Estados e dos Municípłos estão dispostas na própria Constituição." ÁVILA, Humberto. Sisterna Constitucional Tributário. São Paulo: Saraiva, 2004. pg. 107.

53 PAOLA, Leonardo Sperb de. Presunçôes e Ficçōes no Oiretto Tributátio. Belo Horizonte: Dê Rcy, 1997. pg. 174.

S4 ARAúlO. Jakson Borges. ICMS Ficçăo do Fato Gerador na Substituição Tributária. São Paulo: luarez de Oliveira, 200I. pg. 93.

ss Vide artigo 154 da Constituição Federal de 1988. BRASIL. Constituição da República Federativa do Brasil, de 5 de outubro de 1988. 35 ed. São Paulo: Saraiva, 2005. pg. I 17.

56 FERRAGUT, Maria Rita. Presunções no Direito Tributário. São Paulo: Dialética, 2001. pg. 140.

57 SCHERKERKEWITZ, Iso Chaitz. Presunçōes e Fieçōes no Direito Tributário e no Direito Penal Tributário. Rio de Janeiro: Renovar, 2002. pg. 53 
Neste ponto, é fundamental a análise das normas de competência tributária dentro do estudo das presunções e ficções tributárias, principalmente Quando está em discussão Questôes de incidência, o que será, nesse momento, objeto de breve análise.

A respeito da competência tributária ${ }^{58}$, bem leciona Marco Aurélio Grecco, ao dizer que:

A Constituição Federal discrimina competências tributárias entre as várias entidades tributantes; vale dizer, define o âmbito de cabimento da criação de tributos, a partir do Qual cada entidade poderá instituir um tributo a fim de gerar recursos para o desempenho de suas finalidades. A atribuição constitucional de competência tributária poderá adotar, como critério de discriminação, a indicação de uma finalidade a ser buscada ou a especialização de certa materialidade concreta. Quando a Constituição adota o segundo critério, a materialidade da competência tributária (parcela da realidade por ela Qualificada) pode se constituir num fenômeno econômico (p.ex. renda), e nesta medida juridicializado, ou num fenômeno que denote um conteúdo econômico (p. ex. a transmissão da propriedade imobiliária, o contrato de seguro etc). ${ }^{59}$

A discriminação de competências é rígida e exaustiva, outorgando aos entes políticos (União, Estados-Membros, Distrito Federal e Municípios) o direito de tributar os fatos constantes dessa divisão. ${ }^{60}$

Neste aspecto, afirma Eurico Marcos Diniz de Santi: “a competência para instituir impostos é limitada e está rigidamente delineada pela Constituição Federal." ${ }^{61}$

Também, Humberto Ávila leciona:

(...) o Sistema Tributário é um sistema rígido. Essas há muito conhecidas rigidez e exaustividade decorrem de dois fundamentos: de um lado, as regras de competência e a repartição das receitas são intensamente reguladas pela própria Constituição. Todos os impostos da União (art. 153), dos Estados (art. 155) e dos Municípios (art. 156) são definidos pela própria Constituição mesma. (...) A referida rigidez decorre também da repartição de competências para a instituição de cada tributo. O Sistema Tributário Nacional determina, no art. 153 e seguintes, Quais tributos podem sr instituídos pela União, pelos Estados e pelos Municípios. O importante é Que a Constituição não apenas define as hipóteses de incidência, mas também predetermina o conteúdo material para o exercício da competência. Essas prescrições são instituídas pela Constituiçãa toda $(. . .)^{62}$

58 A respeito da competência tributária, vide artigos $6^{\circ}, 7^{\circ}$ e $8^{\circ}$ do Código Tributário Nacional.

59 GRECO, Marco Aurélio. Susbtituição Tributária ICMS, IPl, PIS e COFINS. São Paulo: IOB, s/a. pg. 09.

ø FerRagut, Maria Rita. Presunções no Direito Tributário. São Pauło: Dialética, 200 1. pg. 99

61 SANTl, Eurico marcos Diniz (Coord.). Curso de Espectalizaçăo em Direito Tributário - Estudos Analíticos cm Homenagem a Paulo de Barros Carvalho. Rio de Janeiro, Forense: 2005. pg. 549.

(22 ÁVILA, Humberto. Sistema Constitucional Tributário. São Paulo: Saraiva, 2004. pg. 111. 
Há três aspectos relevantes no tocante à competência tributária. Um deles diz respeito ao fundamento do poder de tributar, ou seja, as pessoas políticas titulares de competências impositivas: a União, Estados-Membros, Distrito Federal e os Municípios; outro aspecto refere-se ao tributo e suas espécies, como reparti-los, referindo a Carta Magna que as pessoas políticas Que formam a Federação poderão instituir os impostos, as taxas e as contribuiçōes de melhoria e; por fim, diz respeito à repartição de competências pela natureza dos fatos jurígenos (suporte fático). ${ }^{63}$

A doutrina atribui à competência tributária determinadas características, Quais sejam: privatividade, ou seja, Quem recebe a atribuição para instituir determinado imposto tem competência privativa, não podendo outra entidade instituí-lo; indelegabilidade ${ }^{64}$, que nos diz Que Quem recebe a competência não pode delegá-la, nem por lei, para outra entidade, cabendo essa função apenas à Constituição Federa!; incaducabilidade, que refere-se a faculdade no seu exercício e que en caso de haver omissão tal exercício não caduca; irrenunciabilidade, Que significa Que não se pode renunciar à competência outorgada, devendo se omitir na instituição do tributo e facultatividade, sendo uma faculdade o seu exercício.

Roque Antônio Carrazza diz que o Princípio da Discriminação de Competências é: (...) a habilitação (...), a faculdade potencial, Que a Constituição confere a determinadas pessoas (as pessoas de direito público interno) para Que, por meio de lei, tributem, evidentemente editando, primeiramente, lei descritiva das hipóteses de incidência (artigo 150, I da Constituição Federal). ${ }^{65}$

A conclusão lógica que pode ser extraída do texto constitucional é que a Constituição Federal não cria tributos, simplesmente atribui competências às pessoas políticas para instituílas através de lei, instituindo, assim, o princípio da legalidade da tributaçãa ${ }^{66}$, Que pode se dar tanto por lei ordinária como por lei complementar. ${ }^{67}$

Diante do citado princípio temos que todas as disposições que se refiram aos elementos Que compõe a exigência do tributo dependem de lei6 ${ }^{88}$, como, por exemplo, Que dizem respeito a sua instituição, extinção, majoração, redução, definição de base de cálculo, fato gerador ou alíuota, definição do sujeito passivo, salvo as exceções previstas constitucionalmente ${ }^{69}$.

6) COÊLHO, Sacha Calmon Navarro. Curso de Direlto Tributário Brasileiro. 4. ed. Rio de Janeiro: Forense, 1999. pg. 67.

64 Nesse aspecto, alirma Hugo de Brito Machado: "a competência tributária é indelegável." MACHADO, Hugo de Brito. Curso de Direito Tributário. 13. ed. São Paulo: Malheiros, 1998. pg. 184.

6s CARRAZZA, Ropue Antonio. Curso de Direito Constitucional Tributário. 3. ed. São Paulo: Revista dos Tribunais, 1991. pg. 146.

${ }^{6}$ COÊLHO, Sacha Calmon Navarro. Curso de Direito Tributário Brasileiro. 4. ed. Rio de laneiro: Forense, 1999. pg. 68.

67 Nesse sentido: BRASIL. Supremo Tribunal Federal. Agravo Regimental no Recurso Extraordinário n० 156.287. SP, da I a Turma do STF, Relator Ministro Celso de Mello, Brasília, D) 20.05.94 PP-[2273 EMENT VOL01745-04 PP-00706.

GRECO, Marco Aurélio. Susbtituiçăo Tributária ICMS, IPI, PIS e COFINS. Săo Paulo: IOB, 190-1. pg. 13.

69 As exceçôes dizem respeito às alíquotas do II, IE, IPI, IOF, CIDE e as Contribuições - vide artigos 153, \$ $1^{\circ} \mathrm{e} 177, \S 4^{\circ}, 1, \mathrm{~b}$ da Constituição Federal. 
Da própria leitura dos artigos 150,1 , e $5^{\circ}, \mathrm{I}, \mathrm{da} \mathrm{CF} / 88$, podemos afirmar Que para a instituição ou aumento de tributos é necessário a edição de le li ${ }^{70}$, de forma Que somente 0 poder legislativo por meio de procedimento legislativo pode instituir ou aumentar tributos. ${ }^{71}$

Não cabe ao legislador se afastar dessa divisão de competências constante na Constituição Federal, seja para mais ou para menos, independentemente do processo legislativo ${ }^{72}$ utilizado. ${ }^{73}$ Ademais, por ser a discriminação de competências rígida e exaustiva, não há Que se falar em modificação por norma infraconstitucional dessa atribuição de competência estabelecida pela Constituição Federal.

A Constituição não abre espaço à fixação de competências tributárias por meio de atos normativos infraconstitucionais, empregando vocábulos Que vinculam o legislador. ${ }^{74}$

Podemos então afirmar Que as presunções e ficções tributárias, Quando utilizadas para a composição da hipótese de incidência, definição de base de cálculo, fato gerador ou alíquota não podem atribuir aos signos empregados na Constituição outros significados Que ali não definidos.

Nessa seara, bem leciona Andrei Pitten Velloso:

(...) o fato de Que os signos empregados pela Constituição para outorgar competências tributárias aos entes políticos possuem efetivamente significados (conceitos), os Quais devem ser respeitados pelo legislador, por estes está jungido em sua atividade legiferante. Entendimento diverso importaria na admissão de competências ilimitadas, o Que não resiste a um mero juízo analítico: a ilimitação é uma nota inerente ao conceito de competência, Que só existe na medida em que outorgada. ${ }^{75}$

A respeito das bases econômicas, o Supremo Tribunal Federal (STF) vedou a utilização de ficçốes Que impliquem extrapolação das bases econômicas, ao analisar a incidência do imposto de importação (II) sobre mercadoria nacional reimportada. Entendeu Que: "Ao considerar estrangeira, para efeito de incidência do tributo, a mercadoria nacional reimportada, o art. 93 do Decreto-lei $n^{\circ} 37 / 66$ criou ficção incompativel com a Constituição de 1946 (...) " e, assim, declarou inconstitucional o dispositivo legal referido ${ }^{76.77}$

T Como bem lembrado por Humberto Ávila, atualmente o Poder Executivo, através de medidas provisórias pode instituir tributos. ÁVILA, Humberto. Sistema Constitucional Tributário. São Paulo: Saraiva, 2004. pg. 121.

71 ÁVILA, lúmberto. Sistema Constitucional Tributário. Săo Paulo: Saraiva, 2004. pg. 120.

72 As espécies legislativas compreendem: emendas à Constituiçäo, leis complementares, leis ordinárias, leis delegadas, medidas provisórias, decretos legislativos ou resoluções. A esse respeito, ver artigo 59 e incisos da CF/88. BRASIL. Constituiçăo da República Fedełativa do Brasil, de 5 de outubro de 1988. 35 ed. São Paulo: Saraiva, 2005. pg, 62.

${ }^{73}$ FERRAGUT, Maria Rita. Presunçōes no Diretto Tributário. Săo Paulo: Dialética, 2001. pg. 99.

74 VELLOSO. Andrei Pitten. Conceitos e Competências Tributárias. São Paulo: Dialética, 2005. pg. 28.

75 VELLOSO, Andrei Pitten. Conceitos e Competência Tributária. São Paulo: Dialética, 2005. pg. 30.

To Ver: BRASIL. Supremo Tribunal Federal. Recurso Extraordinário n ${ }^{\circ}$ 104.306-7/SP, do Pleno do STF; Relator Ministro Octavio Galotti, Brasilia, D) 18.04.1986.

77 Adotando esse mesmo entendimento, ver: BRASIL. Tribunal Regional Federal da $2^{\text {a }}$ Regiáo. MAS 2002.02.01.0005539, Relator Desembargador Federal Ney Fonscca, Rio de Janeiro, Di 02.08.2002. 
Cumpre destacar parte do fundamento da decisão que adotou esse entendimento, cujo Relator foi o Ministro Octavio Galotti:

"Tem-se, na espécie, uma ficção jurídica criada pela legislação ordinária, Que
inseriu, no núcleo da hipótese de incidência do imposto de importação, um
novo elemento, sem observar a necessária correspondência com a previsão
constitucional pertinente. O art. 21,1 , da Constituição, ao definir a tributação
de mercadorias importadas, restringiu o alcance da exação aos bens
estrangeiros, afastando, por conseguinte, a cobrança do imposto em questão,
sobre produtos de fabricação nacional. (...) ao legislador ordinário. (...), ao
ampliar, por um artifício, o conteúdo da regra constitucional, afrontou a própria
natureza e o fundamento do gravame tributário, em detrimento dos
pressupostos enunciados na Constituição." 78

Quanto ao poder que cada ente tributante possui, os artigos 145 ao $162 \mathrm{da} C F / 88$ prevêem regras Que o delimitam constitucionalmente, vetando Qualquer liberdade ao legislador para modificar os fatos Que podem ou Que não podem ser objeto de tributação. ${ }^{79}$

Diferente das ficções Que entendemos não ser possivel a șua utilização, as presunções só podem ser utilizadas se previstas em lei, ou seja, as presunções legais, não podendo, o legislador infraconstitucional, inclusive, alterar ou criar, mediante a equiparação de fatos, a competência de tributar constitucionalmente prevista.

Dessa forma, refere Maria Rita Ferragut:

Regras infraconstitucionais não podem alterar o arquétipo constitucional dos tributos, sendo possível a inovação do sistema apenas com a introdução de enunciado fundado no artigo 154, inciso I, da Carta Magna. E, se é assim, as presunções legais não podem ser utilizadas visando modificar, mediante a equiparação de fatos, a competência de tributar, constitucionalmente conferida aos entes políticos. ${ }^{80}$

Ainda, no Que tange a utilização das presunções, há Quem refira Que tal instituto não tem o condão de alargar a competência tributária, tendo em vista Que as presunções não criam novos fatos típicos (fatos geradores) não previstos na competência da pessoa política tributante, mas apenas permitem Que o fato possa ser indiretamente provado. ${ }^{81}$

Nessa seara, como exemplo podemos referir a responsabilidade tributária por substituiçãao do tomador de serviços mediante cessão de mão-de-obra, relativamente à

78 BRASiL. Supremo Tribunal Federal. Recurso Extraordinário no 104.306-7/SP, do Pleno do STF, Relator Ministro Octavio Galotti, Brasíla, DJ 18.04.1986.

7 ÁVILA, Humberto. Sistema Constitucional Tributário. São Paulo: Saraiva, 2004, pg. 58.

${ }^{\infty}$ FerRAGUT, Maria Rita. Preșunçōes no Direito Tributário. São Paulo: Dialética, 200I. pg. 120.

${ }^{81}$ FERRAGUT, Maria Rita. Presunçōes no Direito Tributário. São Paulo: Dialética, 2001. pg. 99. 
contribuição sobre a folha de pagamento dos segurados a seu serviço, cuịo contribuinte é a empresa prestadora de serviços - artigo 31, da Lei 8.2 I 2/9 I, com redação dada pela Lei $9.711 / 98^{82}$. Nesse caso, o legislador utilizou uma presunção, Qual seja, a de Que o montante devido corresponda a I $1 \%$ do valor na nota, para a retenção e recolhimento pelo tomador quando do pagamento dos serviços, tendo como referência ovalor bruto da nota fiscal ou fatura de prestação de serviços. Ainda, em decorrência da vedação da tríbutação com base de cálculo no fato fictício, o legislador admitiu Que o prestador de serviços possa proceder à compensação dos valores retidos Quando for efetuar o pagamento da contribuição previdenciária de toda a sua folha, bem como de oue o contribuinte tem direito a eventual repetição do montante retido além do devido, na hipótese de não ser possível a compensação integral..$^{83}$

Comentando essa Questão, bem leciona Leandro Paulsen:

"(...) A figura da substituição tributária existe, justamente, para atender a princípios de racionalização e efetividade da tributação, ora simplificando os procedimentos, ora diminuindo as possibilidades de inadimplemento e ampliando garantias de recebimento do crédito etc. Nāo se tem, aQui, de forma alguma, a instituição de nova contribuição. A presunção de um valor a ser recolhido, seja mediante presunção da base de cálculo ou da utilização de outro crédito como o Que foi utilizado em no caso em discussão, é da natureza da substituição tributária e só a descaracteriza, implicando novo tributo ou, se não admitindo constitucionalmente por razões formais ou materiais, implicando "tributação" irregular, caso não fosse possível a compensação ou restituição de eventuais recolhimentos feitos a maior em face do efetivamente devido, considerada a base de cálculo real e a alíquota respectiva. Tendo em conta que não estamos diante de uma nova exação, não há que se falar na necessidade de lei complementar e na vedação do bis in ideme da bitributação (...). ${ }^{84}$

2.1.2 Da Exigibilidade do Tributo - Fato Gerador na Substituição Tributária para Frente - Artigo 150, parágrafo $7^{\circ}$, da Constituição Federal de 1988

No ordenamento jurídico brasileiro o fato gerador presumido foi introduzido pela

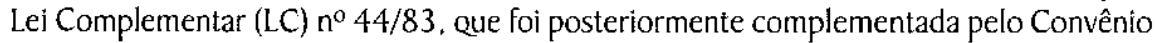
$n^{\circ} 66 / 88^{85}$. criado pelos Estados e Distrito Federal, prevendo Que, em caráter provisório,

82 Ver: BRASil. Lei Ordinária n 9.711 , de 20 de novembro de 1998. Diário Oficial da República Federativa do Brasil, Poder Executivo, Brasília, DF, 21 nov. 1998.

B1 PAULLSEN, Leandro. Direito Tributário. Constituição e Código Tríbutário à Luz da Doutrina e da furisprudência. 6. ed. Porto Alegre: Livfaria do Advogado: Esmafe, 2004. pg. 937.

th PAULSEN, Leandro. Direito Tributário. Constituiçăo e Código Tributário à Luz da Doutrina e da lurisprudência. 6. ed. Porto Alegre: Livraria do Advogado: Esmafe, 2004. pg. 937/938.

${ }^{25}$ Nesse sentido ver: BRASIL. Superior Tribunal de Justiça. Recurso Especial n ${ }^{\circ} 212983 / \mathrm{ES}$, da $2^{\mathrm{a}}$ Turma do ST|, Relator Ministro Francisco Peçanha Martins, Brasília, DJ 10.02.2003 p.176. 
e até a promulgação de lei complementar, esses entes celebrariam convênio, necessário à instituição do Imposto sobre Circulação de Mercadorias e Serviços (ICMS), consoante a Lei Complementar n ${ }^{\circ} 24 / 75 .{ }^{86}$

A constitucionalidade da utilização da substituição tributária para frente passou a ser Questionada perante os tribunais reiteradamente, obtendo êxito os contribuintes em muitos casos, até Que, com o fim de atribuir fundamento de validade às normas jurídicas que dispusessem a respeito dessa espécie de substituiçãa, foi publicada a Emenda Constitucional $\mathrm{n}^{\circ} 03 / 93$, Que instituiu o $\$ 7^{\circ}$ ao artigo 150 da Constituição Federal de $1988 .{ }^{87}$

Assim, desde então, a substituição tributária para frente encontra respaldo na Constituição Federal, no parágrafo $7^{\circ}$ do artigo 150, assim redigido:

$\S 7^{\circ}$. A lei poderá atribuir a sujeito passivo de obrigação tributária a condição de responsável pelo pagamento de imposto ou contribuiçāo, cujo fato gerador deva ocorrer posteriormente, assegurada a imediata e preferencial restituição da Quantia paga, caso não se realize o fato gerador presumido. ${ }^{88}$

A introdução da chamada substituição tributária para frente pela Emenda Constitucional $n^{\circ} 3 / 93$ teve como objetivo, também, facilitar a fiscalização e cobrança, principalmente do ICMS, em setores como o automotivo, o farmacêutico, de bebidas, de combustiveis e outros. ${ }^{89}$

Tal fato nos mostra Que o uso das presunções e ficções, como ocorre nessa espécie de substituição, está diretamente ligado ao Princípio da Praticabilidade, que é aquele que estabelece o dever de se evitar as aplicaçóes complexas da lei, devendo essa ser sempre simplificada, econômica e viável. ${ }^{90}$

lustificando a criação do fato gerador presumido, Eurico Marcos Diniz de Santi, bem relata:

A facilidade na arrecadação e na viabilização de outros aspectos da política tributária justificou a criação de previsão expressa para se antecipar o fato gerador, mas não permitiu a burla do princípio da legalidade: os aspectos Que definem e possibilitam a exigência da antecipação do tributo hão de respeitar a legalidade. ${ }^{\text {? }}$

36 FERRAGUT, Maria Rita. Presunções no Direito Tributário. São Paulo: Dialética, 2001.pg. 119.

aj FERRAGUT, Maria Rita. Presunções no Direito Tributário. São Paulo: Dialética, 2001. pg. 119.

${ }^{88}$ BRASIL. Constituição da República Federativa do Brasil, de 5 de outubro de 1988. 35. ed. São Paulo: Saraiva, 2005. pg. 115.

89 SANTI, Eurico marcos Diniz (Coord.). Curso de Especiatização em Direito Tributário - Estudos Analíticos em Homenagem a Paulo de Barros Carvalho. Rio de Janeiro, Forense: 2005. pg. 546

90 FERraGuT; Maria Rita. Presunções no Direito Tributário. São Paulo: Dialética, 200I. pg. 98.

21 SANT1, Eurico Marcos Diniz (Coord.) Curso de Especialização em Direito Tributário - Estudos Analíticos em Homenagem a Paulo de Barros Carvalho. Rio de Janeiro, Forense: 2005. pg. 549. 
O regime de substituição tributária para frente (progressiva) tem sido objeto de inúmeras discussões doutrinárias ${ }^{92}$ e jurisprudenciais desde a sua instituição. ${ }^{93}$

O dispositivo anteriormente referido contém um requisito de natureza formal exigência de lei para a disciplina - e três reQuisitos substanciais - vinculação, atribuição e devolução do excesso. Assim, somente encontrará fundamento constitucional a norma de antecipação/substituição Que atender cumulativamente a esses Quatro reQuisitos. ${ }^{94}$

Sacha Calmon Navarro Coêlho analisando criticamente o dispositivo em Questão, faz três observaçóes importantes. Por primeiro, nos diz que o referido dispositivo, em nome do princípio da praticabilidade ${ }^{95}$ da tributação, institui no nosso Sistema Tributário um típo novo de substituição tributária para frente, com vista a superar o óbice de cobrar imposto antecipadamente de um substituto por fato gerador de terceiro ainda não praticado; por segundo, Que o dispositivo é imprudente, tendo em vista que não declina os impostos a Que se aplica e; por terceiro, Que ao menos se resolveu o ressarcimento imediato, caso não se realize o fato gerador presumido na substituição, pela cláusula de imediata e preferencial de restituição ao substituído de valor major Que o substituto ${ }^{96} .{ }^{97}$

Grande parte da doutrina brasileira sustentou a inconstitucionalidade da Emenda $n^{\circ}$ 03/93, tendo em vista Que a Constituição Federal aceita tão somente a tributação da capacidade concreta e efetiva do contribuinte, em face do disposto no artigo 145 , $\$ 1^{\circ}$, da CF/88.

Também, passou-se a Questionar se o fato gerador presumido poderia ser declarado inconstitucional por ferir os princípios constitucionais alçados à condição de cláusulas pétreas ${ }^{99} .100$

${ }^{22}$ O doutrinador Eurico Marcos Diniz Santi analisa criticamente essa espécie de substituição tributária e, segundo ele, essa técnica flexibiliza a competência tributária e fundanenta novas hipóteses de incidência correlatas à competência tributária original. SANTI, Eurico Marcos Diniz. (Coord.) Curso de Especialização em Direito Tributário - Estudos Analíticos en Homenagem a Paulo de Barros Carvalho. Rio de laneiro, Forense: 2005. pg. 551 .

${ }^{93}$ A esse respeito, ver citação de parte do artigo de Aroldo Gomes de Mattos publicado na Revista Técnica Dialética sobre a Emenda n ${ }^{\circ} 3 / 93$ constante na obra de Sacha Calmon Navarro Coelho, pg. 6I6. COÊlHO, Sacha Calmon Navarro. Curso de Direito Tributário Brasileiro. 4. ed. Rio de laneiro: Forense, 1999. pg. 616.

94 GRECO, Marco Aurélio. Substituição Tributária - ICMS -- IPI - PIS - COFINS. São Paulo: IOB, [19-]. pg. 77.

25 Há Quem entenda que a praticabilidade não é um princípio jurídico, sendo uma simples tendência para igualar e simplificar, năo levando em consideração os princípios da justiça, da igualdade e da capacidade contributiva.

${ }^{96}$ Essa cláusula, ainda, nos traz duas conclusões: "a) a devolução indica Que somente os impostos sobre circulação, plutifásicos, admitem a substituição para frente; e b) indica, ainda, que os impostos sobre a renda e a propriedade estão excluídos. Neles é impossivel a imediata e preferencial restituição." COÊLHO, Sacha Calmon Navarro. Curso de Direito Tributário Brasileiro. 4. ed. Rio de laneiro: Forense, 1999. pg. 616.

${ }^{7}$ COÊllHO, Sacha Calmon Navarro. Curso de Direito Tributárło Brasileiro, 4. ed. Rio de Janeiro: Forense, 1999. pg. 615.

98 ÁVILA, Humberto. Sistema Constitucional Tributário. São Paulo: Saraiva, 2004. pg. 363.

"2. As cláusulas pétreas estäo previstas no $\$ 4^{\circ}$, do artigo $60 \mathrm{da} \mathrm{CF} / 88$.

${ }^{100}$ FERRAGUT, Maria Rita. Presunçōes no Direito Tributário. São Paulo: Dialćtica, 2001. pg. 118. 
Há Quem afirme que o fato gerador presumido é inconstitucional, embora não seja esse o entendimento Que os Tribunais vem adotando. ${ }^{101}$

O fato gerador presumido exige o pagamento do tributo com base em um mero indício da ocorrência futura do fato típico, sendo, assim, incompatível com os princípios da segurança jurídica, da legalidade, da tipicidade e da capacidade tributária, os euais compreendem os direitos e garantias individuais dos contribuintes. Ademais, pode-se dizer que é incompativel, também, com o disposto no artigo $113, \S \mathrm{I}^{\circ}$, do Código Tributário Nacional ${ }^{102} .{ }^{103}$

O Supremo Tribunal Federal (STF), analisando a possível inconstitucionalidade da substituição tributária para frente, decidiu pela sua constitucionalidade. De acordo com o STF, Quando da análise da exigência do ICMS, entendeu que a Emenda Constitucional no 03 / 93, ao introduzir o parágrafo $7^{\circ}$, ao artigo $150, \mathrm{da} \mathrm{CF} / 88$, apenas aperfeiçoou o instituto da substituição tributária para frente, o Qual já era previsto no nosso sistema jurídico-tributário, ao delinear a figura do fato gerador presumido e ao estabelecer a garantia de reembolso preferencial e imediato do tributo pago quando não verificado o mesmo fato gerador ao final. Ainda, afirmou Que: "A circunstância de ser presumido o fato gerador não constitui óbice à exigência antecipada do tributo, dado tratar-se de sistema instituído pela própria Constituição, encontrando-se regulamentado por lei complementar (...)". ${ }^{104}$

Também, o Pretório Excelso, Quando do julgamento do Recurso Extraordinário (RE) n ${ }^{\circ}$ 2 1 3.396-SP, cujo relator foi o Ministro lìmar Galvão, decidiu, por maioria, ser constitucional o regime de substituição tributária para frente - em Que se exige do industrial, do atacadista, ou de outra categoria de contribuinte, na eualidade de substituto, o recolhimento antecipado do ICMS incidente sobre o valor final do produto cobrado ao consumidor, retirando-se do revendedor ou varejista, substituído, a responsabilidade tributária. O recurso teve por objeto operações realizadas anteriormente à Emenda Constitucional $n^{\circ} 3 / 93$, eue introduziu no art. 150 , da CF, o $\S 7^{\circ}$. Restaram vencidos, no presente caso, os Ministros Carlos Velloso, Marco Aurélio e Sepúlveda Pertence, eue votaram no sentido da inconstitucionalidade do referido regime no período anterior à $\mathrm{EC} \mathrm{n}^{\circ} 3 / 93$, por entenderem Que não poderia o legislador ordinário autorizar a antecipação do ICMS sem Que houvesse ocorrido o seu fato gerador. ${ }^{105} 106$

10! FERRAGUT, Maria Rjta. Presunçōes no Direito Tributário. São Paulo: Dialética, 2001. pg. 121.

${ }^{102}$ Prescreve o referido parágrafo o seguinte: " $\$ 1{ }^{\circ}$ A obrigaçăo principal surge com a ocorrência do fato gerador. tem por objeto o pagamento de tributo ou penalidade pecuniária e extingue-se juntamente com o crédito dela decorrente."

103 FERRAGUT, Maria Rita. Presunçốes no Direito Tributário. São Paulo: Dialética, 2001. pg. 120.

104 Vide julgamento da ADIN $1.85 \mathrm{I}$, pelo Pleno do STF, cujo Relator foi o Ministro llmar Galvão. BRASIL. Supremo Tribunal Federal. Ação Direta de Inconstitucionalidade $n^{\circ} 1.851 / \mathrm{AL}$, Pleno do STF, Relator Ministro llmar Galvão, Brasília, DI DATA 22-11-2002 PP-00055 EMENT VOL-02092-01 PP-00139.

10 Nesse mesmo sentido, ver: ÁVILA, Humberto. Sistema Constitucional Tributátio. São Paulo: Saraiva, 2004. pg. 363.

"1/6 Ainda, esses mesmos argumentos foram adotados quando do julgamento do Al-AgR 240057-2, cujo Relator foi o Ministro Néri da Silveira. BRASIL. Supremo tribunal Federal. Agravo Regimental em Agravo de lnstrumento $n^{\circ}$ 240057-2, Segunda Turma do STF, Relator Ministro Néri da Silveira. Brasilia. D) 26-05-2002. 
O Superior Tribunal de Justiça (ST)) manifestou-se pela legalidade da existência da substituição tributária para frente, afirmando ser uma realidade Que está presente no nosso ordenamento tributário ${ }^{107}$. De acordo com o STI, a exigência de pagamento antecipado, via substituição tributária, não é ilegal, pois com o pagamento antecipado não ocorre recolhimento do imposto antes da ocorrência do fato gerador. Ainda, entenderam que o momento da incidência do tributo fixado em lei não se confunde com a cobrança do tributo, de molde que a substituição tributária não "agride o ordenamento jurídico tributário". ${ }^{108}$ Nesse mesmo sentido, foi o entendimento utilizado nos julgamentos do Recurso Especial (RESP) no 56776/ SP, cujo relator foi o Ministro Francisco Peçanha Martins, Diário de Justiça (D) 15.03 .1999 p. $198^{109}$ e Recurso Ordinário em Mandado de Segurança (RMS) n ${ }^{\circ}$ 9428/ES, cujo relator foi o Ministro Franciulli Netto, DI 19.02.2001 p. $145^{110}$.

O Tribunal do Estado do Rio Grande do Sul (TIRS) tem decidido pela possibilidade da existência da substituição tributária para frente em face da ocorrência do fato gerador presumido. Ainda, tem reconhecido Que o contribuinte substituído tem direito de creditarse do ICMS pago a maior, pelo seu substituto legal, na hipótese de o valor da mercadoria, Quando da sua posterior saída, vir a revelar-se menor do Que aquele que serviu de base de cálculo à tributação antecipada, tanto Quanto tem ele a mesma obrigação de suplementar eventual diferença na hipótese de o valor da mercadoria vir a revelar-se a maior. "il

Sobre esse aspecto. em relação ao ICMS, cabe dizer Que a expressão Qual seja "cujo fato gerador deva ocorrer posteriormente, assegurada a imediata e preferencial restituição da Quantia paga, caso não se realize o fato gerador presumido" pode ser interpretada em dois sentidos. Por primeiro, Que é assegurada a restituição da Quantia paga a maior Quando o contribuinte pagar antecipadamente o imposto com base em fato gerador presumido, mas se verificar, posteriormente, Que o valor do fato gerador real (base de cálculo) foi inferior ao

${ }^{107}$ Vide: BRASIL. Superior Tribunal de lustiça. Recurso Ordinário em Mandado de Segurança nº 8420/GO, 2a Turma do ST], Relator Ministro Francisco Falcão, Brasília, Dl 25.10 .1999 p. 70

10 BRASIL. Superior Tribunal de Justiça. Recurso Ordinário em Mandado de Segurança no 8773/GO, I Turma do ST], Rełator Ministro losé Delgado, Brasília, D) 02.08.1999 p. 137

109 BRASIL. Superior Tribunal de Justiça, Recurso Especial no 56776/SP, 2a Turma do STI, Relator Ministro Francisco Peçanha Martins, Brasilia, D) 15.03.1999 p. 198

${ }^{110}$ BRASIL. Superior Tribunal de Justiça. Recurso Ordinário em Mandado de Segurança no 9428/ES, $2^{3}$ Turma do STI, Relator Ministro Franciulli Netto, Brasília, DI 19.02.200I p. 145

"I Sobre esse entendimento, ver os seguintes julgados: BRASIL. Tribunal de Justiça do Estado do Rio Grande do Sul. Apelação Cível no 70005036165 , $1^{a}$ Câmara Cível do TJRS, Relator Desembargador Irineu Mariani, Porto Alegre, Data do Julgamento 18.12.2002, BRASIL. Tribunal de lustiça do Estado do Rjo Grande do Sul. Embargos Infringentes n ${ }^{\circ} 70006371959$. ${ }^{a}$ Grupo de Câmaras Cíveis do TiRS, Relator Desembargador Roque Joaquim Volkweiss, Porto Alegre, Data do Julgamento 06.06.2003, BRASIL.

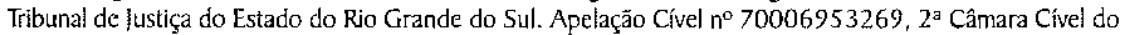
TJRS, Relator Desembargador Roque joaquim Volkweiss, Porto Alegre, Data do Julgamento I5.10.2003 e BRASIL. Tribunal de Justiça do Estado do Rjo Grande do Sul. Embargos Infringentes no 70007303795. $f^{\text {a }}$ Grupo de Câmaras Cívcis do TIRS, Relator Desembargador Irineu Mariani, Porto Alegre, Data do lulgamento 07.II.2003. 
presumido; por segundo, Que somente ocorrerá à restituição do pagamento efetuado com base em fato gerador presumido Quando não se verificar a ocorrência do fato gerador real. ${ }^{1 / 2}$

Alguns Estados optaram pelo sentido da primeira interpretação (São Paulo e Pernambuco) e outros pela segunda. O Supremo Tribunal Federal já decidiu nos dois sentidos, mas sinaliza atualmente para a primeira posição. ${ }^{1 / 3}$

O segundo entendimento não nos parece a melhor interpretação dada à segunda parte do dispositivo em análise. $O$ contribuinte tem direito a restituição da diferença apurada sempre que se verificar Que o fato gerador Que serviu de base de cálculo à tributação antecipada tenha ocorrido a menor, assim como tem direito o Fisco de cobrar eventual diferença caso se apure eventual aumento na base de cálculo.

Tal fato se deve tendo em vista Que a presunção no fato gerador presumido na substituição tributária para frente admite prova em contrário (presunção relativa - iurris tantum). Assim, tanto o contribuinte como o Fisco tem a possibilidade de provar que o fato gerador real ocorreu diversamente do fato gerador presumido.

A presunção instituída na substituição tributária para frente não se trata de presunção juris et de jure, o Que já foi objeto de análise pelo ST).$^{114}$

Outra Questão Que merece destaque no estudo do fato gerador presumido diz respeito de definir a partir de Que momento a obrigação tributária torna-se exigivel, se o fato gerador não ocorreu, ainda, Qual o real montante da obrigação e Quem é seu sujeito passivo. Temos Que, em todos esses questionamentos, somente a lei poderá definir, assim, o novo fato tributário, nova base de cálculo e o sujeito passivo, conforme já concluído anteriormente. "is

Quanto às ficções, à luz dos pressupostos estudados brevemente no primeiro capítulo desse artigo, podemos afirmar Que não podem ser objeto de utilização para a instituição de hipóteses de incidência e criação de obrigaçōes no Direito Tributário, não sendo abrangidas na substizuição tributária para frente, no Que tange ao fato gerador presumido. As ficçōes não respeitam o Princípio da Capacidade Contributiva e violam as normas de competência tributária, vez Que atribuem ao fato características Que não são reais.

Diferente é o que pode ser verificado com o instituto de presunções, sendo legítimo o seu uso no âmbito do Direito Tributário brasileiro. Tal instituto, inclusive, tem previsão estabelecida constitucionalmente, no Que tange à substituição tributária para frente, conforme ora estudado.

12 SANTI, Eurico Marcos Diniz (Coord) Curso de Especializaçăo em Direito Tributário - Estudos Analíicos em Homenagem a Paulo de Barros Carvalho. Rio de Janeiro, Forense: 2005. pg. 547.

${ }^{113}$ SANTI, Eurico Marcos Diniz (Coord.) Curso de Especialização em Direito Tributário - Estudos Analiticos em Homenagem a Paulo de Barros Carvatho. Rio de laneiro, Forense: 2005. pg. 547.

it/ Ver: BRASIL. Superior Tribunal de lustiça. Recurso Especial n ${ }^{\circ}$ 203551/MG, 2a Turma do STI, Retator Ministro Ari Pargendler, Brasilia, D) 03.05.1999 p. 138

115 SANT1, Eurico Marcos Diniz (Coord.) Curso de Especialização em Direito Tributário - Estudos Analíticos em Homenagem a Paulo de Barros Carvalho. Rio de laneiro, Forense: 2005. pg. 548. 
As presunções, ao admitirem a realização de prova em contrário, instituem a possibilidade de restituição imediata e preferencial Quando o valor real for diferente do valor da base de cálculo anteriormente utilizado para a cobrança do tributo, ou seja, Quando não realizado o fato gerador presumido, tal Qual presumido. Assim, o valor da base de cálculo não será uma mera presunção, mas sim o valor real da operaçâo, tenha ocorrido ele a maior ou menor sobre o valor presumido.

Essa possibilidade de restituição por parte dos contribuintes ou a possibilidade do Fisco na cobrança da diferença eventualmente apurada caso a base de cálculo real seja superior a base de cálculo presumida vem de encontro ao princípio da capacidade contributiva e das normas de competência tributárias estabelecidas na $\mathrm{CF} / 88$ anteriormente estudadas.

\section{CONCLUSÃO}

As Presunções e as Ficções não são sinônimos e não podem ser utilizadas com o mesmo significado. Presunçâo é a conclusão ou o convencimento antecipado de uma verdade ou existência provável de um fato ainda desconhecido extraído mediante um fato conhecido e conexo, podendo ou não ser refutada mediante a realização de prova em contrário. Fiç̧ão é uma criação da lei de uma realidade jurídica diversa da realidade real, ou seja, supõe a existência de efeitos ou verdades jurídicas Que na realidade não existem sobre determinado fato.

As presunções estão presentes no nosso ordenamento jurídico, são uma realidade no Direito Tributário e, cada vez mais, se tornam essenciais ao exercício da atividade arrecadatória.

As presunções encontradas tanto na Constituição Federal como em leis infraconstitucionais são criadas em face do princípio da praticabilidade, ou seja, com o fim de buscar a melhor aplicação da lei (Que deve ser de forma simplificada e eficaz), auxiliando o Estado na potencialização da eficácia arrecadatória e no combate à sonegação de tributos.

Entretanto, tais presunções devem ser apilicadas com limites e não podem viołar as normas de competência tributárias, tampouco o direito dos contribuintes de se oporem às presunções mediante prova em contrário, com a possibilidade de restituição imediata $\mathrm{e}$ preferencial Quando o valor real for diferente do valor da base de cálculo anteriormente utilizado para a cobrança do tributo, forte nos princípios constitucionais da capacidade contributiva, da igualdade e da legalidade.

Os operadores do direito, contudo, não têm dedicado a atenção Que esse assunto merece, razão pela Qual, em muitas decisões, não vemos o entre a simplificação da arrecadação e a observância dos direitos dos contribuintes, pois ainda encontramos julgados que não reconhecem o direito do contribuinte de ser restituído Quando o valor real for diferente do valor da base de cálculo anteriormente utilizado para a cobrança do tributo. 
Por fim, no Que tange as ficções, por sua vez, por atribuírem ao fato características não reais, não podem ser objeto de utilização no Direito Tributário, principalmente no Que tange a criação de obrigações tributárias, sob pena de violarem o Princípio da Capacidade Contributiva e as normas de competência tributárias estabelecidas na Constituição Federal de 1988.

\section{REFERÊNCIAS BIBLIOGRÁFICAS}

1. AMARO, Luciano. Direito Tributário Brasiteiro. 6. ed. São Paulo: Saraiva, 2001. 487p.

2. ARAúlo, lackson Borges. ICMS Ficção do fato Gerador na Substituição Tributária. São Paulo: Editora Juarez de Oliveira, 2001. 168p.

3. ÁVILA, Humberto. Sistema Constitucional Tributário. São Paulo: Saraiva, 2004. 601p.

4. BECKER, Alfredo Augusto. Teoria Geral no Direito Tributário. 3. ed. São Paulo: Lejus, 1998.686p.

5. BONILHA, Paulo Celso Bergstrom. Da Prova no Processo Administrativo Tributário. 2. ed. São Paulo: Dialética, 1997. 127p.

6. BRASIL. Código Tributário Nacional. 29. ed. São Paulo: Saraiva, 2000. 9|4p.

7. BRASIL. Constituição da República Federativa do Brasil, de 5 de outubro de [988. 35 ed. São Paulo: Saraiva, 2005. 422p.

8. BRASIL. Lei Ordinária $\mathrm{n}^{\circ} 9.711$, de 20 de novembro de 1998. Diário Oficial da República Federativa do Brasil, Poder Executivo, Brasília, DF, 21 nov. 1998

9. BRASIL. Superior Tribunal de lustiça. Recurso Especial no 203551/MG, 2 Turma do ST), Relator Ministro Ari Pargendler, Brasília, D) 03.05.1999 p. 138.

10. BRASIL. Superior Tribunal de lustiça. Recurso Especial n $212983 / E S$, da $2^{a}$ Turma do ST], Relator Ministro Francisco Peçanha Martins, Brasília, D] 10.02.2003 p. 176.

I I. BRASIL. Superior Tribunal de Justiça. Recurso Especial no 56776/SP, 2a Turma do ST\}, Relator Ministro Francisco Peçanha Martins, Brasília, Dl 15.03.1999 p. 198.

12. BRASIL. Superior Tribunal de Justiça. Recurso Ordinário em Mandado de Segurança $\pi^{\circ}$ 8420/GO, 2a Turma do STI, Relator Ministro Francisco Falcăo, Brasília, D| 25. 10.1999 p. 70.

13. BRASIL. Superior Tribunal de Justiça. Recurso Ordinário em Mandado de Segurança n ${ }^{\circ}$ 9428/ES, $2^{\text {a }}$ Turma do STJ, Relator Ministro Franciulli Netto, Brasília, D] 19.02 .2001 p. 145.

14. BRASIL. Superior Tribunal de lustiça. Recurso Ordinário em Mandado de Segurança no 8773/GO, [a Turma do ST], Relator Ministro José Delgado, Brasília, DI 02.08. I999 p. I 37

15. BRASIL. Supremo Tribunal Federal. Açăo Direta de Inconstitucionalidade no 1.85 1/AL, Plano do STF, Relator Ministro Ilmar Galvão, Brasiliba, DI DATA 22-11 -2002 PP-00055 EMENT VOL02092-0I PP-00139.

16. BRASIL. Supremo Tribunal Federal. Agravo Regimental em Agravo de Instrumento ${ }^{\circ}$ 240057-2, $2^{\mathrm{a}}$ Turma do STF, Relator Ministro Néri da Silveira, Brasília, D| 26-05-2002.

17. BRASIL. Supremo Tribunal Federal. Agravo Regimental no Recurso Extraordinário ${ }^{\circ}$ 156.287 SP, da Ia Turma do STF, Relator Ministro Celso de Mello, Brasilia, DI 20.05.94 PP-12273 EMENT VOL-0I 745-04 PP-00706.

18. BRASIL. Supremo Tribunal Federal. Recurso Extraordinário no 104.306-7/SP, do Pleno do STF, Relator Ministro Octavio Galotti, Brasília, DI 1 8.04.1986

19. BRASIL. Supremo Tribunal Federal. Recurso Extraordinário no $67146 / \mathrm{MG}$, da la Turma do STF, Relator Ministro Luis Galotti, Brasília, DI 28/1 1/1969. 
20. BRASIL. Tribunal de Justiça do Estado do Rjo Grande do Sul. Apelação Cível no 70005036165, la Câmara Cível do TỊRS, Relator Desembargador Irineu Mariani, Porto Alegre, Data do fulgamento 18.12 .2002 .

21. BRASIL. Tribunal de lustiça do Estado do Rio Grande do Sul. Apelação Cível no 70006953269, 2 Câmara Cível do TIRS, Relator Desembargador Roque Joaquim Volkweiss, Porto Alegre, Data do Julgamento 15. I0.2003.

22. BRASIL. Tribunal de lustiça do Estado do Rjo Grande do Sul. Embargos Infringentes no 70006371959. 1a Grupo de Câmaras Cíveis do TIRS, Relator Desembargador Roque loaquim Volkweiss, Porto Alegre, Data do fulgamento 06.06.2003.

23. BRASIL. Tribunal de Justiça do Estado do Rio Grande do Sul. Embargos Infringentes no 70007303795, I a Grupo de Câmaras Cíveis do T|RS, Relator Desembargador Irineu Mariani, Porto Alegre, Data do fulgamento 07.1].2003.

24. BRASIL. Tribunal Regional Federal da 2a Região. MAS 2002.02.01.0005539, Relator Desembargador Federal Ney Fonseca, Rjo de laneiro, D/ 02.08.2002

25. CARRAzZA, Roque Antonio. Curso de Direito Constitucional Tributário. 3. ed. São Paulo: Revista dos Tribunais, 1991. 486 p.

26. COÊLHO, Sacha Calmon Navarro. Curso de Direito Tributário Brasileiro. 4. ed. Rio de Janeiro: Forense, 1999. 80 Ip.

27. Covello. Sérgio Carlos. A Presunção em Matéria Civil. São Paulo: Saraiva, $1983.139 \mathrm{p}$.

28. FERRAGUT, Maria Rita. Presunções no Direito Tributário. São Paulo: Dịalética, 2001 . $175 p$.

29. GRECO, Marco Aurélio. Substituição Tributária - ICMS - IPI - PIS - COFINS. São Paulo: 1OB, [19-]. 188p.

30. HOFFMANN, Susy Gomes. Teoria da Prova no Direito Tributário. São Paulo, Copola Livros, 1999. 246p.

31. MACHADO, Hugo de Brito. Curso de Direito Tributário. 13 ed. São Paulo: Malheiros, 1998. 400p.

32. MIRANDA, Pontes de. Tratado de Direito Privado. 4. ed. São Paulo: Revista dos Tribunais, 1983, t. III. $511 \mathrm{p}$.

33. PAOLA, Leonardo Sperb. Presunções e Ficções no Direito Tributário. Belo Horizonte: Del Rey, 1997.278p.

34. PAULSEN, Leandro. Direito Tributário. Constituição e Código Tributário à Luz da Doutrina e da lurisprudência. 6. ed. Porto Alegre: Revista dos Tribunais: Esmafe, 2004. $1.365 p$.

35. PROLIK, Escritório Augusto. As Presunções Fiscais e o Lançamento Tributário. Disponivel em: <http://www.prolik.com.br/34-01.html>. Acesso em 17 nov. 2004

36. SANTI, Eurico marcos Diniz (Coord.) Curso de Especialização em Direito Tributário - Estudos Analíticos em Homenagem a Paulo de Barros Carvalho. Rio de Janeiro, Forense: 2005 . $1185 \mathrm{p}$.

37. SCHERKERKEWITZ, Iso Chaitz. Presunções e Ficções no Direito Tributário e no Direito Penal Tributário. Rio de laneiro: Renovar, 2002. 244p.

38. SOARES, Carlos Dalmiro da Silva. Efeitos e Natureza Jurídica do Parcelamento Administrativo de Créditos Tributários. Disponfivel em: <http://wwwl.jus.com.br/doutrina/ texto.asp?id =1338>. Acesso em: I7 nov. 2004.

39. TENÓRIO, Igor e MAIA, J. Mota. Dicionário de Direito Tributário. São Paulo: José Bushatskey, 1975. 415p.

40. VELLOSO, Andrei Pitten. Conceitos e Competências Tributárias. São Paulo: Dialética, 2005. $351 \mathrm{p}$. 